diplomatic compromise admitting the Russian province of The Ukraine as a Member of the United Nations.

The author states, furthermore, that "It is impossible to recognize legally a state which does not exist de facto." When the United States and Great Britain recognized the non-existent state of Czecho-Slovakia in the first World War there was no legal impediment to this extraordinary political act of recognition. Incidentally, it may be observed that this was a fantastic instance of what Hans Kelsen characterizes as the "constitutive" effect of recognition : it certainly created a new state!

In referring to the tests applied by individual nations in respect to recognition the author states that: "There is no risk in saying that the basic objective tests relating to statehood and governmental capacity have never been ignored." The fact is, as illustrated in the non-recognition of the Communist regime in China by the United States, the decisive factor has generally been a purely political one. And conversely, the recognition of this same government by Great Britain would seem to have been actuated by the exigencies of its economic and political interests in the Far East.

Professor Alexandrowicz-Alexander has focused attention on some of the controversial aspects of diplomatic practice with respect to recognition. In seeking, however, to restrict the freedom of nations to determine the nature of their diplomatic relations with states and governments of doubtful, and possibly of unfriendly, conduct, he is pleading for a reform which may not be either wise or practicable. The cognition of the facts of international relations may often place limitations on the nature and the extent of diplomatic intercourse. Though there may exist an attenuated kind of de facto recognition in some instances, full, formal, and unrestricted recognition may be accorded only as a sovereign political prerogative. It is not a judicial, or quasi-judicial, function.

Philip Marshall Brown

\title{
SELF-DETERMINATION IN THE UNITED NATIONS
}

Recent discussions in United Nations organs, and one or two actions taken, indicate a slowly dawning realization that the term "self-determination," long a theoretical subject, has become one of practical importance and immediate urgency, badly in need of legal definition. The problem now developing around this term may be of wider importance than the "cold war." The rising tide of nationalism has brought along an almost frantic revival of the concept of "self-determination" made famous by President Wilson; and now some very strange meanings are being given to it. Discussion and action have been related to Trusteeship, to Non-Self-Governing Territories, and to Human Rights; but the discussion has not reached down to fundamental principles and practical methods. It has been conducted, indeed, in what is unfortunately becoming the tone of the General Assembly: noble utterances on behalf of high-sounding principles which would 
not be translated into responsible action by any of the states whose delegates make the speeches. These utterances take no account of reason, or justice, or practicality; they simply bespeak desires. There are many questions which must be answered before self-determination can be made into a workable system. It is the purpose of this comment to suggest some of these questions.

Article 76 of the Charter refers to "progressive development toward selfgovernment or independence," in the case of trust territories. The question has arisen, though little formal discussion has taken place concerning it, as to how (and by whom) it is to be determined that a trust area is ready for independence or for self-government. More attention might have been given to such questions when the disposition of the Italian colonies was put before the General Assembly, but the discussion was entirely political and, after much squabbling, it was decided that Libya was to be independent at once (after a year of preparation) and Italian Somaliland in ten years. No one asked whether these areas had sufficient cohesiveness or capability to stand alone; "self-determination" was arranged from the outside. Now it appears that Libya is, at least from the economic viewpoint, unable to sustain herself. Is it the responsibility of the United Nations which created Libya to give it financial support, or to support it against an aggressor should one appear? Who gained anything by this act of "self-determination"? Of course, these are not trust territories; but is the same procedure to be followed when someone raises the question of independence for a trust territory?

Article 73 of the Charter requires "Members of the United Nations which have or assume responsibilities for the administration of territories whose peoples have not yet attained a full measure of self-government" to transmit, "subject to such limitations as security and constitutional considerations may require," information "relating to economic, social and educational conditions in the territories for which they are respectively responsible." They are also to develop these areas toward self-government. From the beginning, there has been uncertainty as to the areas upon which governments should report under Article 73 e. Colonial Powers have claimed the right to determine for themselves which of their territories are self-governing, and have bitterly opposed efforts to require political information from them; anti-colonial opinion has pushed hard against them in both respects.

At the Fifth General Assembly, a resolution (334 V) was adopted, calling upon the Special Committee (now known as the "Committee on Information from the Non-Self-Governing Territories") "to examine factors which should be taken into account in deciding whether any territory is or is not a territory whose people have not yet attained a full measure of self-government." This committee reported that political advancement might lead either to independence or to free association in a union, and laid down certain requirements for each. These requirements (too long for quotation 
here) set standards which few-if any-of the so-called sovereign states of today could meet: e.g., "independence or complete control over its external relations and internal affairs," or "complete autonomy in economic and social affairs." They also require certain specified democratic procedures which are far from being universally accepted and which are not necessarily of enduring value. The Sixth Assembly set up an "Ad Hoc Committee on Factors" (resolution $567 \mathrm{VI}$ ) which revised the above report somewhat; by the time this comment is printed, the report will probably have been considered by the Seventh Assembly.

The chances are good that the enthusiastic supporters of self-determination will add a few more criteria, from the viewpoint of compelling colonial Powers to surrender more, but without thinking that they are making it more difficult for such an area to measure up to the standards set. Nevertheless, this first effort to satisfy the urgent need for criteria deserves commendation, and it is to be hoped that with further study more practical answers can be found.

The above criteria are with reference to self-government; many delegates however, have a much wider meaning for self-determination. The Sixth General Assembly adopted resolution $545 \mathrm{VI}$, which, after a far-fetched preamble referring to every possible clause of the Charter,

1. Decides to include in the International Covenant or Covenants of Human Rights an article on the right of all peoples and nations to self-determination in reaffirmation of the principles enunciated in the Charter of the United Nations. This article shall be drafted in the following terms: "All peoples shall have the right of selfdetermination." ...

2. Requests the Commission on Human Rights to prepare recommendations concerning international respect for the self-determination of peoples. ...

No one bothered to explain what is meant by self-determination, or by peoples, and the unfortunate Commission on Human Rights, being bound to exact words, had much trouble with its assignment. M. Nisot of Belgium asked five incisive questions which were often referred to but never answered. Some of the delegates went beyond self-government or independence, and sought to apply the concept to states already independent and sovereign. Thus Mr. Waheed (Pakistan) thought that the right of selfdetermination should be proclaimed "in such a way as to prevent weak peoples from being dominated by strong peoples." Mr. Azkoul (Lebanon) said that the point of the whole question was "that of countries that had lost their independence as a result of aggression." In the view of the United States Delegation (Mrs. Roosevelt)

the principle of self-determination applied not only to peoples which had not yet attained their independence but also to politically independent States which needed protection from external pressure, threats, the use of force, and subversive activities. 
According to a Yugoslav proposal (Mr. Jeremovic) "the right of peoples to self-determination belonged to both non-self-governing and sovereign peoples as long as their independence could be threatened by other States," and he wanted to set up "a body to watch over all the peoples, independent or otherwise, whose right of self-determination was frequently threatened." He also did not believe "that the exercise of the right of peoples to selfdetermination could be ensured unless every individual was entitled to exercise it." Thus the concept of self-determination was broadened to include collective security, and extended to individuals as well as groups or peoples. Mr. Morozov (Soviet Union) said that self-determination meant, among other things, the evacuation of foreign troops from sovereign states. Mr. Valenzuela (Chile) asserted that self-determination

should enable any State in a condition of economic subordination to recover full sovereignty, by acquiring complete control over its own natural resources even if this meant expulsion or nationalization of certain (i.e., foreign) undertakings.

Thus the concept would stand superior to law or contractual obligations. Perhaps the solution offered by the Polish delegate (Boratynski) best of all represented the view of the Assembly. He said "the search for definitions was unnecessary as self-determination should be proclaimed for all."

It should be noted, too, that throughout the debate, the question was constantly raised whether the action taken should include all peoples and minorities, or should apply only to those territories listed as Non-Self-Governing Territories, i.e., to the colonial Powers. The latter view was strongly upheld by India and the Soviet Union, and finally prevailed. Why should the champions of self-determination fail to call for the independence of Alaska?

The United Nations must do much better than this if it is to solve the difficult and urgent problems which will face it as one group after another, encouraged by such wild talk, will claim their independence at the hands of the United Nations. A definition must be found for "people"': manifestly, it cannot be permitted that any group whatsoever can claim independence as of right. This would mean anarchy; the reductio ad absurdum would be that each individual could become a sovereign state. It is probable that no automatic definition can be made, and that some authority must be found to decide when a people is ready for independence: What shall this authority be, and how shall it act? Most of all it will need criteria for determination.

It cannot be assumed, as it has been in these debates, that independence is always a good thing for any particular group: Has it been good for Libya Nor can it be assumed that colonies only are entitled to selfdetermination. It is an interesting historical fact that as soon as a national group has attained independence, it becomes as imperialistic as any of those whom it formerly condemned. Thus India, immediately after the Inde- 
pendence Act, swallowed up Hyderabad by force and is now well on the way to swallowing Kashmir-to mention only the two of the Princely States whose cases have come before the United Nations. At the same time, India was leading a movement for the independence of Indonesia; and as soon as the Indonesian Republic was set up, this new government sought to swallow up East Indonesia, and is now reaching for New Guinea. If the United Nations believed that the Republic of Indonesia had a right of self-determination as against The Netherlands, why should it not also support the claim of the Republic of the South Moluccas as against Indonesia? What is to be done about Tunis? and Laos and Cambodia? and any number of others which will come along?

Such questions reveal the difficulty which faces the United Nations today-the lack of criteria for reaching such decisions. In the good old days, a people got their independence by fighting for it, as did the United States of America, or by having a powerful friend, as did Panama. But now the appeal is to the United Nations. If the United Nations is to decide, it must have authority, law (or at least guiding principles), and responsibility for carrying out its decisions. (I leave aside the question of its present authority, and note that it can in any case bring enormous pressures to bear.) What becomes of the "right of revolution," of secession? Indeed, if the United Nations is to decide, can there any longer be "self". determination? Will ambitious peoples be willing to have their fate de. termined by the chance of some Member State bringing their claim up, and having a decision reached upon purely political grounds? Or would they prefer to have the decision reached upon the basis of accepted criteria?

And what will all this do to the United Nations itself? The states now under attack-the colonial Powers-are the ones without which the United Nations could not exist. They feel no guilt; they have committed no illegality in possessing colonies-though they may admit to mistakes in administration-in most cases they have improved the situation of the peoples under their control; they have made large investments to which they have an indubitable legal right; they have advanced their peoples (some 600 millions of them) toward self-government and, in some cases-British Commonwealth and Philippines-to independence. Can it be expected, as a practical matter, that they would willingly submit to a majority of votes from states whose responsibility and contribution are small as compared with theirs? Can they be expected to welcome new states to add to the majority of votes against them in the United Nations? They are on the defensive, and are prepared to make concessions; but, right or wrong, they cannot be expected to support a United Nations in which a majority of states seek to deprive them not only of territories but of their investment in those territories. And if the new states are unable to maintain themselves, and call upon the United Nations for help, it would be the same colonial Powers which would have to assume the burden of economic or 
military support, for the states now clamoring against them are unable to assume the responsibility.

Self-determination is a noble ideal, and worth working for ; it has failed in the past because of the lack of an international law or organization able to apply it. With the United Nations, it becomes possible to work out criteria and methods; there is no more important and urgent task before the United Nations today. But the criteria established must be based upon justice and upon common sense, and little respect has been shown to either in the current debates. It is not merely the people concerned, but the community of nations, which has an interest; reckless application of the principle could easily lead to great dangers for the community of nations. A new field of international law is being opened up; it deserves the most serious study by the most responsible persons upon whom the United Nations can call.

Clyoe Eagleton

\section{NEW UNITED STATES POLICY LIMITING SOVEREIGN IMMUNITY}

A new United States position with respect to the immunity from jurisdiction of the local courts enjoyed by foreign governments engaged in commerce was demonstrated in the letter of May 19, 1952, from the Acting Legal Adviser of the Department of State to the Acting Attorney General. ${ }^{1}$ In this letter Acting Legal Adviser Jack B. Tate wrote:

The Department of State has for some time ${ }^{2}$ had under consideration the question whether the practice of the Government in granting immunity from suit to foreign governments made parties defendant in the courts of the United States without their consent should not be changed. The Department has now reached the conclusion that such immunity should no longer be granted in certain types of cases. . . .

A study of the law of sovereign immunity reveals the existence of two conflicting concepts of sovereign immunity, each widely held and firmly established. According to the classical or absolute theory of sovereign immunity, a sovereign cannot, without his consent, be made a respondent in the courts of another sovereign. According to the newer or restrictive theory of sovereign immunity, the immunity of the sovereign is recognized with regard to sovereign or public acts (jure imperii) of a state, but not with respect to private acts (jure gestionis). ${ }^{3}$. . .

1 Department of State Bulletin, Vol. 26 (June 23, 1952), p. 984.

2 On April 9, 1948, a press officer of the Department of State announced that the Department was reconsidering the policy of requesting immunity for foreign governmentowned and government-operated merchant vessels in view of the increasing tendency of such vessels to engage in commercial operations. The New York Times, April 10, 1948, p. 27, col. 3. This announcement was issued in response to questions concerning the grant of immunity to the Soviet vessel Rossia, 1948 A.M.C. 814 (S.D.N.Y., April 6, 1948).

$3 \mathrm{Mr}$. Tate added: "There is agreement by proponents of both theories, supported by practice, that sovereign immunity should not be claimed or granted in actions with respect to real property (diplomatic and perhaps consular property excepted) or with respect to the disposition of the property of a deceased person even though a foreign sovereign is the beneficiary." 